\title{
Pelatihan Branding dan Digital Marketing Pengelola Obyek Wisata Curug Rahong Desa Cimanggu Kabupaten Pandeglang
}

\author{
Retno Dyah Kusumastuti ${ }^{1 *}$, Prasetyo $\mathrm{Hadi}^{2}$, Ria Maria Theresia ${ }^{3}$, \\ Muhammad Ikhsan Amar ${ }^{4}$ \\ ${ }^{1}$ Fakultas Ilmu Sosial dan Ilmu Politik Universitas Pembangunan Nasional Veteran, Jakarta, 12450 \\ ${ }^{2}$ Fakultas Ekonomi dan Bisnis Universitas Pembangunan Nasional Veteran, Jakarta, 12450 \\ ${ }^{3}$ Fakultas Kedokteran Universitas Pembangunan Nasional Veteran, Jakarta, 12450 \\ ${ }^{4}$ Fakultas Ilmu Kesehatan Universitas Pembangunan Nasional Veteran, Jakarta, 12450 \\ Author E-mail: retnodyah@upnvj.ac.id
}

\begin{abstract}
A B S T R A K
Desa Cimanggu memiliki potensi sebagai destinasi wisata. Desa ini sendiri sebenarnya juga memiliki salah satu obyek wisata, yaitu Curug Rahong. Namun, sejauh ini Bumdes dan Pokdarwis Desa Cimanggu belum mampu menarik banyak wisatawan untuk datang di desa tersebut. Hal ini dikarenakan belum efektifnya kegiatan pemasaran yang dilakukan oleh Bumdes dan Pokdarwis Desa Cimanggu. Dikarenakan adanya permasalahan tersebut, tim pengabdian dari UPN “Veteran” Jakarta melakukan kegiatan pelatihan branding dan pemasaran digital untuk Bumdes dan Pokdarwis Desa Cimanggu. Pelatihan branding dan pemasaran digital untuk Bumdes dan Pokdarwis Desa Cimanggu dilakukan mulai dari 24 Juni 2020 hingga 10 Juli 2020. Pelatihan dilakukan secara daring melalui tatap maya dan diskusi dengan memanfaatkan platform Google Meet, mengingat tidak memungkinkan untuk melakukan kunjungan ke Desa Cimanggu dikarenakan adanya pandemi Covid - 19. Pelatihan tersebut dilakukan dalam 3 pertemuan, dan materi yang disampaikan adalah mengenai brand destinasi pariwisata, konsep branding dan promosi, serta marketing communication. Kedepannya sesudah pandemi Covid - 19 berakhir, pelatihan dapat dilanjutkan dengan lebih intensif melalui pertemuan tatap muka, Focus Group Discussion (FGD), dan latihan serta praktik lebih lanjut, sehingga pihak Bumdes dan Pokdarwis Desa Cimanggu dapat memiliki kapabilitas branding dan pemasaran digital yang lebih baik.
\end{abstract}

Kata Kunci: Branding, pemasaran digital, Curug Rahong.

\section{A B S T R A C T}

Cimanggu Village has a potential as a tourist destination. The village itself also has one of the tourist destinations, namely Curug Rahong. However, so far Bumdes (Village Owned Enterprise) and Pokdarwis (Tourism Promotion Group) in Cimanggu Village have not been able to attract many tourists to visit the village. This is due to the ineffectiveness of the marketing activities which are carried out by Bumdes and Pokdarwis in Cimanggu Village. To help alleviate this problem, the community service team from UPN 
"Veteran" Jakarta decided to conduct branding and digital marketing training activities for Bumdes and Pokdarwis in Cimanggu Village. The training activities for Bumdes and Pokdarwis in Cimanggu Village was conducted from 24th June 2020 to 5th August 2020. The training was carried out through virtual lectures and discussions using the Google Meet platform, since it was not possible to visit Cimanggu Village due to the Covid-19 pandemic. The training was conducted in four meetings, and the materials that were given explained about the tourism destination brand, the concept of branding and promotion, as well as marketing communication. In the future, after the Covid - 19 pandemic has been eradicated, the training would be continued more intensively through face-to-face meetings, Focus Group Discussions (FGD), and further training and practice, to enable Bumdes and Pokdarwis in Cimanggu Village have better branding and digital marketing capabilities.

Key word: Branding, Digital Marketing, Curug Rahong, Tourism

Copyright $(\odot 2020$ Authors. This is an open access article distributed under the Creative Commons Attribution License, which permits unrestricted use, distribution, and reproduction in any medium, provided the original work is properly cited.

\section{PENDAHULUAN}

Desa Cimanggu merupakan salah satu desa yang berada di Kecamatan Cimanggu, Kabupaten Pandeglang, Banten. Luas wilayah desa ini adalah $12,22 \mathrm{~km}^{2}$, atau $6,43 \%$ dari luas wilayah Kecamatan Cimanggu (BPS Kabupaten Pandeglang, 2019). Desa Cimanggu berjarak 207 kilometer dari Jakarta, dan dapat ditempuh dalam waktu 5 jam dari Jakarta. Desa Cimanggu masih termasuk di dalam area Taman Nasional Ujung Kulon, serta jaraknya tidak jauh sejumlah obyek wisata yang sudah cukup terkenal, seperti Pantai Tanjung Lesung, Pulau Umang, Pulau Panaitan, dan Pulau Peucang. Wisatawan yang akan berkunjung ke Taman Nasional Ujung Kulon juga sering melintas di desa ini, mengingat di desa ini terdapat jalan akses menuju Taman Nasional Ujung Kulon. Hal-hal diatas memberikan potensi bagi Desa Cimanggu sebagai destinasi wisata. Hal ini mengingat desa ini memiliki potensi untuk menarik para wisatawan yang hendak mengunjungi Taman Nasional Ujung Kulon atau obyek wisata lain di sekitar desa ini. Desa ini sendiri sebenarnya juga memiliki salah satu obyek wisata, yaitu Curug Rahong. Curug Rahong merupakan air terjun yang terletak di selatan Desa Cimanggu (Gambar 1 menunjukkan pemandangan Curug Rahong). Selain Curug Rahong, di Desa Cimanggu juga terdapat rumah pohon yang dapat dikunjungi wisatawan. Selain itu, juga terdapat wisata alam dan tur mengelilingi desa dengan ditemani pemandu (Gambar 2 menunjukkan salah satu daya tarik lain dari Desa Cimanggu, yaitu sambal goreng bunga honje yang merupakan hidangan khas Desa Cimanggu).

\section{MASALAH}

Pada tahun 2018, Desa Cimanggu tercatat memiliki penduduk sebanyak 2917 jiwa (1491 laki-laki dan 1426 perempuan). Mayoritas penduduk Desa Cimanggu bekerja di sektor pertanian, yaitu $42,5 \%$ dari total penduduk yang bekerja. Sisanya bekerja di sejumlah sektor lainnya, seperti industri dan kerajinan, perdagangan dan pariwisata, serta jasa (BPS Kabupaten Pandeglang, 2019). Di Desa Cimanggu sendiri masih terdapat cukup banyak penduduk yang belum sejahtera. Berdasarkan data BPS Kabupaten Pandeglang pada tahun 2017, tercatat bahwa terdapat 103 keluarga prasejahtera $(11,94 \%$ dari total keluarga), 121 keluarga sejahtera tahap I (14,03\% dari total keluarga), dan 142 keluarga sejahtera tahap II $(16,47 \%$ dari total keluarga) di Desa Cimanggu (BPS Kabupaten Pandeglang, 2019). Menurut BKKBN, keluarga prasejahtera merupakan keluarga yang belum mampu memenuhi kebutuhan dasarnya atau berada pada kemiskinan ekstrim, sedangkan keluarga sejahtera tahap I dan keluarga sejahtera tahap II meskipun sudah mampu memenuhi kebutuhan dasarnya, namun belum memiliki pendapatan 
yang cukup besar dan hanya cukup untuk memenuhi kebutuhan-kebutuhan dasar (Faturochman \& Agus Dwiyanto, 1998). Hal ini berarti menunjukkan bahwa terdapat 366 keluarga di Desa Cimanggu yang berpenghasilan rendah atau berada pada kemiskinan ekstrim $(42,45 \%$ dari total keluarga) (BPS Kabupaten Pandeglang, 2019).

Untuk mengatasi permasalahan kemiskinan di Desa Cimanggu, salah satu hal yang dapat dilakukan adalah dengan memanfaatkan potensi pariwisata di Desa Cimanggu. Pemerintah Desa (Pemdes) Desa Cimanggu sendiri sebenarnya sudah berusaha untuk memanfaatkan potensi pariwisata tersebut dengan menjadikan Desa Cimanggu sebagai desa wisata. Badan Usaha Milik Desa (Bumdes) Desa Cimanggu memiliki peran sebagai pengelola desa wisata dan obyek wisata Curug Rahong bersama dengan Kelompok Sadar Wisata (Pokdarwis) Desa Cimanggu. Namun masih terdapat sejumlah permasalahan yang menyebabkan sektor pariwisata belum dapat secara maksimal menyejahterakan masyarakat Desa Cimanggu. Permasalahan yang paling utama adalah Bumdes dan Pokdarwis Desa Cimanggu belum mampu menarik banyak wisatawan untuk datang di desa tersebut. Sejauh ini kebanyakan wisatawan hanya sekadar melintas saja dan belum tertarik untuk mampir atau mengunjungi Desa Wisata Cimanggu. Hal ini disebabkan oleh kegiatan pemasaran yang belum efektif dilakukan oleh Bumdes dan Pokdarwis Desa Cimanggu. Bumdes dan Pokdarwis Desa Cimanggu sejauh ini sudah memanfaatkan berbagai metode untuk memasarkan Desa Wisata Cimanggu, yaitu melalui brosur, media sosial (Instagram dan Facebook), word of mouth, dan situs internet (Kusumastuti, Hardy, \& Amar, 2020). Namun, sejauh ini kegiatan pemasaran yang dilakukan oleh Bumdes dan Pokdarwis Desa Cimanggu masih belum mampu menjangkau banyak calon wisatawan, sehingga belum dapat menciptakan kesadaran (awareness) calon wisatawan terhadap keberadaan Desa Wisata Cimanggu. Hal ini mengakibatkan belum banyak wisatawan yang tertarik untuk mengunjungi Desa Wisata Cimanggu dan lebih memilih untuk mengunjungi obyek wisata lain di sekitar Desa Cimanggu Taman Nasional Ujung Kulon, Pulau Umang, Pulau Panaitan, dan Pulau Peucang). Penyebab utama dari belum efektifnya kegiatan pemasaran yang dilakukan oleh Bumdes dan Pokdarwis Desa Cimanggu adalah pihak Bumdes dan Pokdarwis Desa Cimanggu juga belum memiliki kapabilitas dalam melakukan pemasaran secara digital sekaligus membangun merek (branding) Desa Wisata Cimanggu. Padahal hal tersebut penting untuk meningkatkan daya saing Desa Wisata Cimanggu dan menarik wisatawan, sehingga wisatawan tidak lagi hanya sekedar melintas Desa Cimanggu untuk menuju obyek wisata lainnya. Dikarenakan adanya permasalahan tersebut, tim pengabdian dari UPN "Veteran" Jakarta melakukan kegiatan pelatihan branding dan pemasaran digital untuk Bumdes dan Pokdarwis Desa Cimanggu (Gambar 3. menunjukkan mengenai materi yang akan disampaikan dalam pelatihan). Tujuan dari kegiatan-kegiatan ini adalah untuk meningkatkan daya saing Desa Cimanggu dalam menarik wisatawan, sehingga diharapkan potensi pariwisata di Desa Cimanggu dapat benar-benar dimaksimalkan untuk meningkatkan kesejahteraan penduduk Desa Cimanggu serta membantu pengentasan kemiskinan di Desa Cimanggu.

Terdapat sejumlah materi yang disampaikan dalam kegiatan kegiatan pelatihan branding dan pemasaran digital untuk Bumdes dan Pokdarwis Desa Cimanggu, yaitu:

1. Pelatihan mengenai branding destinasi wisata. Branding merupakan kegiatan untuk meningkatkan nilai dari suatu barang atau jasa dengan memanfaatkan kekuatan merek dari barang atau jasa tersebut (Kotler \& Keller, 2012). Pelatihan yang diberikan adalah mengenai branding untuk membangun kekuatan merek dari Curug Rahong dan Desa Wisata Cimanggu, sehingga nilai dari Curug Rahong dan Desa Wisata Cimanggu meningkat di mata konsumen.

2. Pelatihan mengenai promosi destinasi wisata. Promosi merupakan kegiatan untuk mengenalkan suatu produk ke konsumen, dalam rangka menarik konsumen dan 
meyakinkan konsumen untuk membeli produk tersebut (Kotler \& Keller, 2012). Pelatihan yang diberikan adalah mengenai promosi untuk mengenalkan Curug Rahong dan Desa Wisata Cimanggu kepada turis, sehingga turis tertarik untuk mengunjungi Curug Rahong dan Desa Wisata Cimanggu.

3. Pelatihan mengenai marketing communication destinasi wisata. Marketing communication merupakan kegiatan yang dilakukan oleh perusahaan untuk memberitahukan dan mengingatkan konsumen mengenai produk dan merek yang dimiliki oleh perusahaan tersebut (Kotler \& Keller, 2012). Pelatihan yang diberikan adalah mengenai marketing communication untuk memberitahukan dan mengingatkan turis mengenai keberadaan Curug Rahong dan Desa Wisata Cimanggu, sehingga turis tertarik untuk mengunjungi Curug Rahong dan Desa Wisata Cimanggu.

4. Pelatihan mengenai proses pemasaran destinasi wisata. Proses pemasaran merupakan suatu proses yang terdiri dari sekumpulan kegiatan pemasaran yang terintegrasi (analisis dan riset pasar, pricing, dan promosi) (Prisgunanto, 2006). Pelatihan yang diberikan adalah mengenai proses pemasaran dalam rangka melaksanakan kegiatan pemasaran Curug Rahong dan Desa Wisata Cimanggu, sekaligus mengintegrasikan kegiatan branding, promosi, dan marketing communication untuk Curug Rahong dan Desa Wisata Cimanggu.

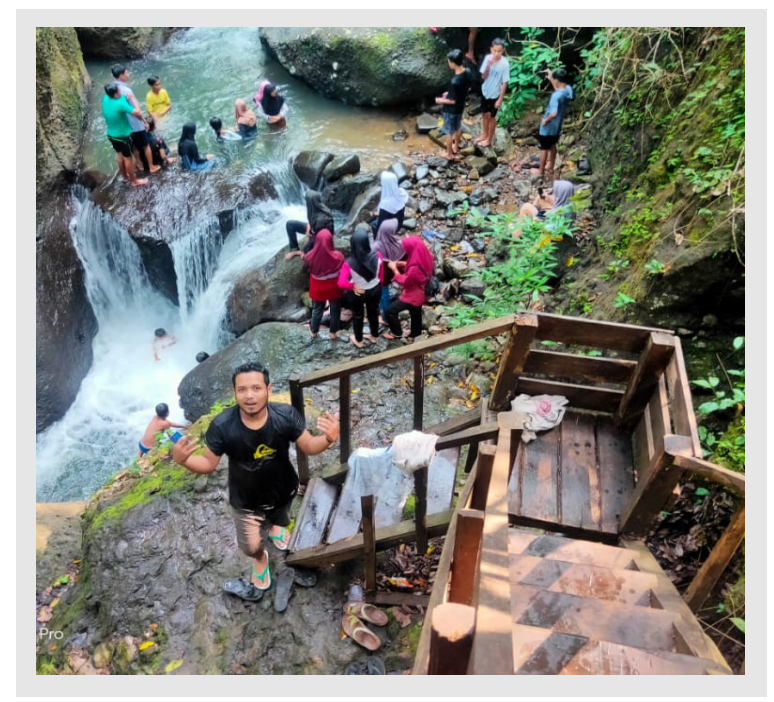

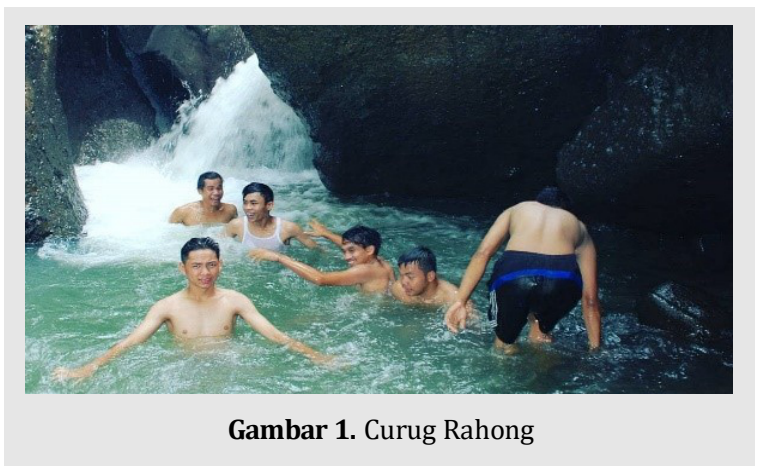

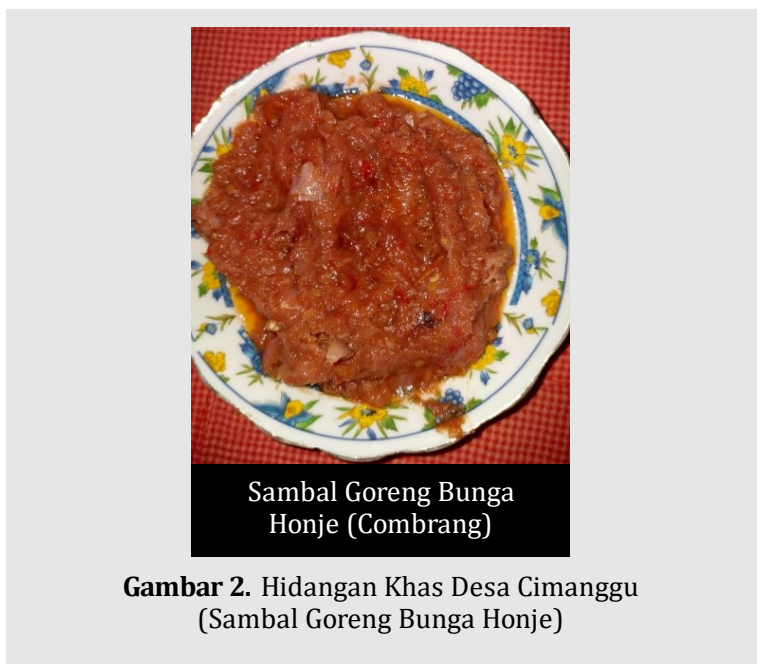

\section{METODE PELAKSANAAN}

Pelatihan branding dan pemasaran digital untuk Bumdes dan Pokdarwis Desa Cimanggu pada awalnya akan dilakukan melalui kunjungan secara rutin oleh tim pengabdian dari UPN "Veteran" Jakarta. Dalam rangka pelaksanaan kegiatan pelatihan, tim pengabdian berencana melakukan sejumlah kegiatan, yaitu: 1) ceramah; 2) latihan dan praktik; 3) Focus Group Discussion (FGD) dan brainstorming. Namun dikarenakan terjadi pandemi Covid-19, terdapat sejumlah pembatasan perjalanan sehingga tim pengabdian dari UPN "Veteran" Jakarta tidak dapat melakukan kunjungan ke Desa Cimanggu. Selain itu, tim pengabdian dari UPN "Veteran" Jakarta juga berasal dari daerah yang cukup parah terdampak oleh Covid-19 (Kota Jakarta Selatan dan Kota Depok), sehingga pihak Bumdes dan Pokdarwis Desa Cimanggu tidak dapat menerima kehadiran tim pengabdian dari UPN "Veteran" Jakarta. Oleh karena itu, sesuai dengan kesepakatan dengan pihak Bumdes dan Pokdarwis Desa Cimanggu, maka pelatihan dilakukan secara daring melalui 


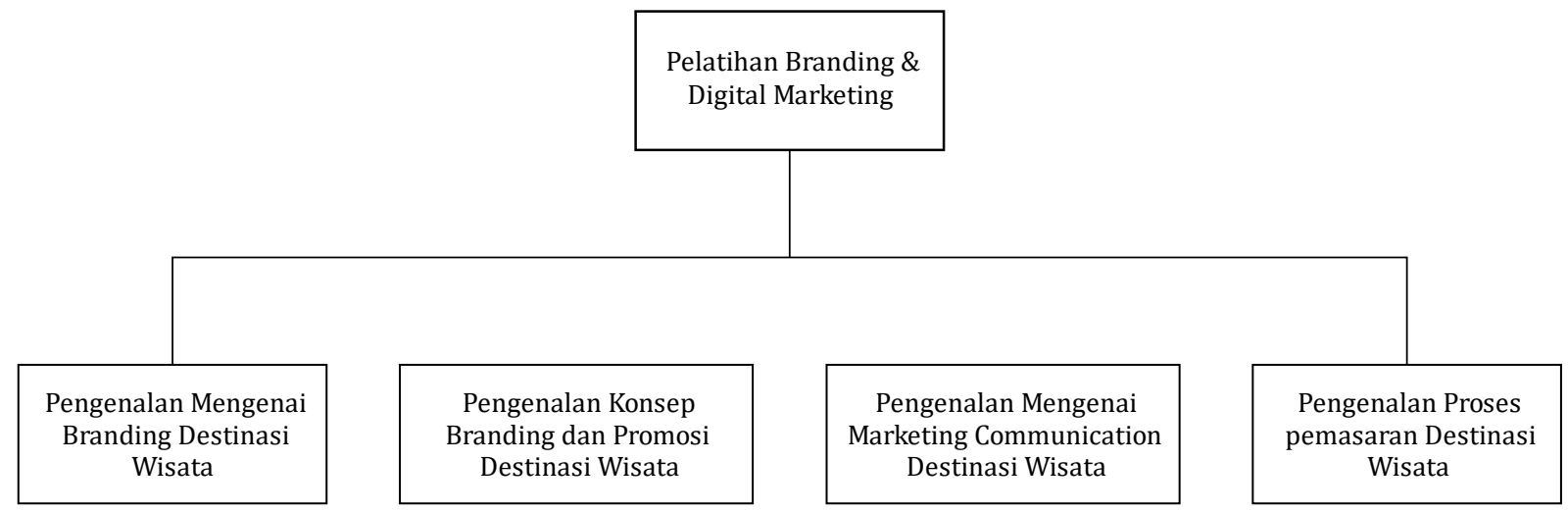

Gambar 3. Materi yang Disampaikan Dalam Pelatihan

tatap maya dan diskusi dengan memanfaatkan platform Google Meet.

\section{HASIL DAN PEMBAHASAN}

Pelatihan branding dan pemasaran digital untuk Bumdes dan Pokdarwis Desa Cimanggu dilakukan mulai dari 24 Juni 2020 hingga 5 Agustus 2020 oleh tim pengabdian dari UPN "Veteran" Jakarta. Pelatihan ini diikuti oleh Kepala Desa Cimanggu (Yayat Supiyat), perwakilan Bumdes Desa Cimanggu (Suryati), dan perwakilan Pokdarwis Desa Cimanggu (Ima Karmila Karim) (Tabel 1. menampilkan daftar lengkap peserta yang mengikuti kegiatan pelatihan). Pelatihan dilakukan secara daring melalui tatap maya dan diskusi dengan memanfaatkan platform Google Meet (Gambar 4. menampilkan foto- foto mengenai kegiatan pelatihan melalui Google Meet). Pelatihan dilakukan dalam 4 pertemuan, dimana pada pertemuan pertama materi yang disampaikan adalah materi mengenai branding destinasi wisata. Pada pertemuan kedua, materi yang disampaikan adalah mengenai konsep branding dan promosi destinasi wisata. Untuk pertemuan ketiga, materi yang disampaikan adalah mengenai marketing communication destinasi wisata sedangkan untuk pertemuan keempat, materi yang disampaikan adalah mengenai proses pemasaran destinasi wisata (Tabel 2. menampilkan tanggal pelatihan dan materi pelatihan yang disampaikan). Sesudah pelatihan selesai dilaksanakan, setiap peserta mendapat sertifikat dari tim pengabdian dari UPN “Veteran” Jakarta (Gambar 5. menampilkan sertifikat pelatihan yang didapat peserta).
Tabel 1. Daftar Peserta Pelatihan

\begin{tabular}{cll}
\hline Nomor & Nama Peserta & \multicolumn{1}{c}{ Jabatan } \\
\hline 1 & Yayat Supiyat & Kepala Desa Cimanggu \\
\hline 2 & Suryati & $\begin{array}{l}\text { Perwakilan Bumdes/Pokdarwis } \\
\text { Desa Cimanggu }\end{array}$ \\
\hline 3 & Ima Karmila Karim & $\begin{array}{l}\text { Perwakilan Bumdes/Pokdarwis } \\
\text { Desa Cimanggu }\end{array}$ \\
\hline 4 & Solihin & $\begin{array}{l}\text { Perwakilan Bumdes/Pokdarwis } \\
\text { Desa Cimanggu }\end{array}$ \\
\hline
\end{tabular}

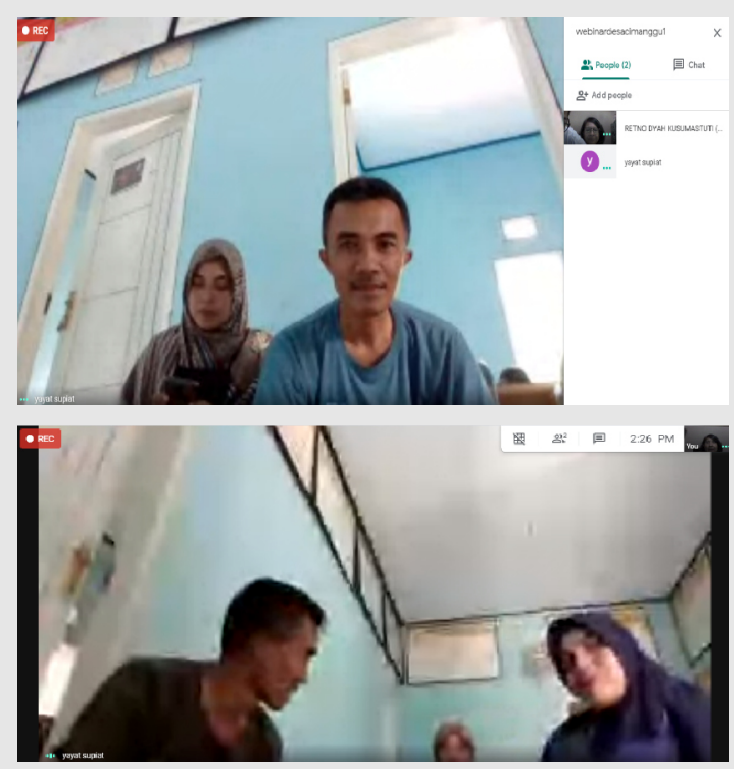

Gambar 4. Foto Kegiatan Pelatihan Secara Daring

Tabel 2. Tanggal Pelatihan dan Materi Pelatihan

\begin{tabular}{cll}
\hline Nomor & Tanggal Pelatihan & \multicolumn{1}{c}{ Materi Pelatihan } \\
\hline 1 & 24 Juni 2020 & Brand Destinasi Wisata \\
\hline 2 & 1 Juli 2020 & $\begin{array}{l}\text { Konsep Branding dan Promosi } \\
\text { Destinasi Wisata }\end{array}$ \\
\hline 3 & 15 Juli 2020 & $\begin{array}{l}\text { Marketing Communication } \\
\text { Destinasi Wisata }\end{array}$ \\
\hline 4 & 5 Agustus 2020 & $\begin{array}{l}\text { Proses Pemasaran Destinasi } \\
\text { Wisata }\end{array}$ \\
\hline
\end{tabular}




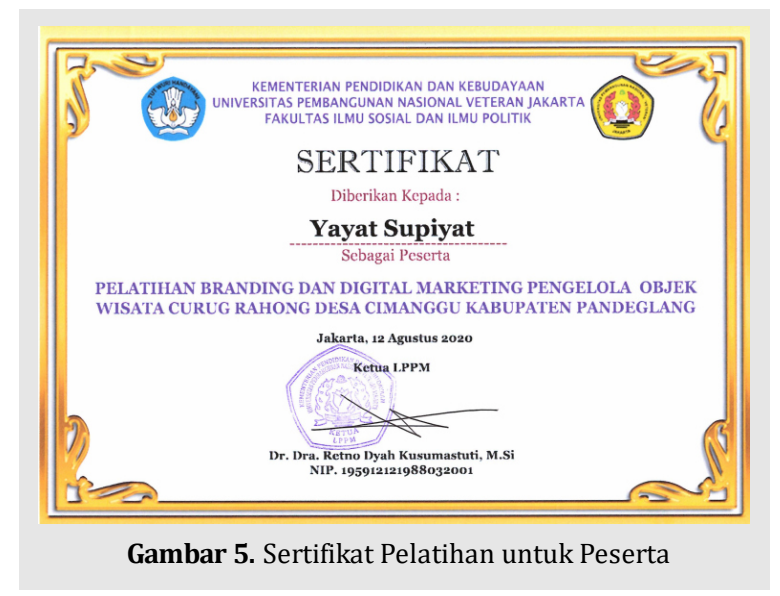

\section{SIMPULAN DAN SARAN \\ Simpulan}

Desa Cimanggu memiliki potensi sebagai destinasi wisata, mengingat lokasinya yang masih termasuk di dalam area Taman Nasional Ujung Kulon, serta jaraknya tidak jauh sejumlah obyek wisata yang sudah cukup terkenal, seperti Pantai Tanjung Lesung, Pulau Umang, Pulau Panaitan, dan Pulau Peucang. Desa ini sendiri sebenarnya juga memiliki salah satu obyek wisata, yaitu Curug Rahong. Pemerintah Desa (Pemdes) Desa Cimanggu sendiri sebenarnya sudah berusaha untuk memanfaatkan potensi pariwisata tersebut melalui Badan Usaha Milik Desa (Bumdes) Desa Cimanggu dan Kelompok Sadar Wisata (Pokdarwis) Desa Cimanggu. Namun masih terdapat sejumlah permasalahan, dimana permasalahan yang paling utama adalah Bumdes dan Pokdarwis Desa Cimanggu belum mampu menarik banyak wisatawan untuk datang di desa tersebut. Hal ini dikarenakan kegiatan pemasaran yang dilakukan oleh Bumdes dan Pokdarwis Desa Cimanggu masih belum mampu menjangkau banyak calon wisatawan, sehingga belum dapat menciptakan kesadaran (awareness) calon wisatawan terhadap keberadaan Curug Rahong dan Desa Wisata Cimanggu, serta belum mampu mendorong wisatawan untuk datang mengunjungi Curug Rahong dan Desa Wisata Cimanggu. Penyebab utama dari belum efektifnya kegiatan pemasaran yang dilakukan oleh Bumdes dan Pokdarwis Desa Cimanggu adalah pihak Bumdes dan Pokdarwis Desa Cimanggu juga belum memiliki kapabilitas dalam melakukan pemasaran secara digital sekaligus membangun merek (branding) Desa Wisata Cimanggu. Dikarenakan adanya permasalahan tersebut, tim pengabdian dari UPN "Veteran" Jakarta melakukan kegiatan pelatihan branding dan pemasaran digital untuk Bumdes dan Pokdarwis Desa Cimanggu. Pelatihan branding dan pemasaran digital untuk Bumdes dan Pokdarwis Desa Cimanggu dilakukan mulai dari 24 Juni 2020 hingga 5 Agustus 2020 oleh tim pengabdian dari UPN "Veteran" Jakarta. Pelatihan dilakukan secara daring melalui tatap maya dan diskusi dengan memanfaatkan platform Google Meet, mengingat tidak memungkinkan untuk melakukan kunjungan ke Desa Cimanggu dikarenakan adanya pandemi Covid-19. Pelatihan tersebut dilakukan dalam 4 pertemuan. Pada 4 pertemuan tersebut, disampaikan materi mengenai mengenai branding destinasi wisata, promosi destinasi wisata, marketing communication destinasi wisata dan proses pemasaran destinasi wisata.

\section{Saran}

Kedepannya, diharapkan sesudah pandemi Covid -19 berakhir, pelatihan ini dapat dilanjutkan dan dilakukan dengan lebih intensif melalui pertemuan tatap muka, Focus Group Discussion (FGD), dan latihan serta praktik lebih lanjut, sehingga pihak Bumdes dan Pokdarwis Desa Cimanggu dapat memiliki kapabilitas branding dan pemasaran digital yang lebih baik. Kedepannya juga diharapkan tim pengabdian dapat menyampaikan materi yang lebih dalam mengenai kegiatan pemasaran untuk Bumdes dan Pokdarwis Desa Cimanggu, khususnya mengenai kegiatan pemasaran untuk menjangkau lebih banyak turis dan kegiatan pemasaran untuk meningkatkan loyalitas turis agar mau berkunjung lagi ke Curug Rahong dan Desa Wisata Cimanggu. 


\section{DAFTAR PUSTAKA}

BPS Pandeglang. (2019). Kecamatan Cimanggu Dalam Angka 2019. Pandeglang: BPS Pandeglang.

Faturochman, \& Dwiyanto, A. (1998). Validitas dan Reliabilitas Pengukuran Keluarga Sejahtera. Populasi, 9(1), 37-49.

Kotler, P., \& Keller, K. L. (2012). Marketing Management. New Jersey: Pearson Education, Inc.

Kusumastuti, R. D., Hardy, F. R., \& Amar, M. I. (2020). Promotion Activities for Curug Rahong Tourism Village to Boost Tourists Arrival. International Journal of Business Studies, 4 (3), 146-157.

Prisgunanto, I. (2006). Komunikasi Pemasaran Strategi \& Taktik. Bogor: Ghalia Indonesia. 